\title{
鍼炎学部学生の高齢者のイメージに関する研究 ー老人ホーム実習による変化-
}

\author{
水沼国男 ${ }^{1)} \quad$ 高橋則人 ${ }^{2)}$ 鶴 浩幸 ${ }^{2)}$ 松本 $\quad$ 勅 ${ }^{2)}$ \\ 1) 明治鍼众大学 東洋医学基礎教室 \\ 2) 明治鍼众大学 老年鍼尒医学教室
}

要 旨

【目的】学生の高齢者に対するイメージは、プラスとマイナスの両面があり、マイナス のイメージが強ければ高齢者に積極的に関わることができないと思われる。実習を通じ て学生の高齢者に対するイメージがどのように変化したかを明らかにすることは実習の 教育効果を評価する上で意義が大きい。そこで、実習前後の高齢者に対するイメージな どの変化について調査した。

【方法】4年生を対象に実習前後にアンケート調査を行った。

【結果】有効回答数は、実習開始時 106 名（有効回答率 $89.8 \%$ )、実習終了時 56 名（有 効回答率 $47.5 \%$ ）であった。イメージが変わった学生は、 $56 \%$ と半数を超えていた。 そのうちマイナスのイメージは、身体面の不自由さや会話の難しさ等の実感からくるも のであり、プラスのイメージは、高齢者と触れ合って理解が深まったことによるもので あった。

【考察】実習により高齢者に対する認識が高まり、イメージが改善した者が多く見られ たが、一方で、高齢者へのマイナスのイメージを抱く者があり、マイナスイメージをで きるだけ少なくするような実習前および実習中の働きかけが必要であると考える。

キーワード : アンケート、高齢者イメージ、介護実習、学生

\section{I . はじめに}

我々は、これまでに学生の高齢者に対する考え 方やイメージの現状および教育による変化を検討 するために、第 1 段階として明治鍼尒大学鍼尒学 部の平成 12 年度の 1 年生から 4 年生の 4 学年を対 象に高齢者のイメージについてアンケート調査を 行つた。その結果、高齢者をイメージする年齢は
60 歳以上が約 9 割であり、また、学生は高齢者に 対してプラスとマイナスのイメージがあり、前者 は精神機能および社会的存在で強く、後者は身体 機能で強い傾向がみられたことを報告した ${ }^{1}$ 。

学生の高齢者に対するマイナスイメージが強け れば、高齢者と積極的に関わることができない、 また、関わることがストレスとなるといった悪循 
環になり、実習にも影響があらわれると考えられ る。このことからプラスイメージを持つ機会にな るような実習をすることが必要である。従つて、 実習体験を通じて学生の高齢者のイメージがどの ように変化しているのか、その実態を明らかにす ることは、教育効果を評価する上で重要である。

そこで今回我々は、明治銊尒大学の 4 年生を対 象に、特別養護老人ホームにおける老年ケア実習 の感想、実習前後での高齢者に対するイメージの 変化について調査した。

\section{II. 方 法}

1. 調査の対象および方法

対象は、明治鍼众大学鍼众学部の平成 12 年度、 4 年生の計 118 名とした。調查は、平成 12 年 4 月 の老年ケア実習前のオリエンテーション時と9月 から 12 月の各グループの実習終了後に、無記名 の質問用紙によるアンケートを行った。アンケー 卜を実施する時に趣旨や目的、アンケートを行う ことによって不利益がないことを説明し実施した。 実習前の調査項目は、高齢者のイメージ、介護・ 介助経験の有無、介護保険や特別養護老人ホーム 等への訪問経験および高齢者への鍼众治療に関す る考え方等であり、また実習終了後の調查項目は、 各実習に関する感想や高齢者に接してみてのイメー ジの変化、鍼众実習、介護実習および高齢者の疑 似体験の感想とした。回答方法は、高齢者のイメー ジの変化は記述式とし、各実習に関する種々の感 想は、選択法としたが、選択肢のうち「その他」 の内容については記述式とした。実習前の学生の 高齢者に対するイメージ調査結果の分析は、学生 が記述した高齢者のイメージを「身体機能」「精 神機能」「社会的存在」「全体像を描いたイメージ」 の大きく4つに分けた。さらに前の4つのカテゴ リーを小カテゴリーに分けた。すなわち「身体機 能」は、「外観」「身体の衰え」に、「精神機能」 は、「性格・心理的特徵」と「知的特徽」に、「社 会的存在」は、「生活者としての視点」「人生の価 值や生きがい」「全体像を形容詞で」および「自 分との関わり」の小カテゴリーに分類し、分析に あたつて文章中よりカテゴリーに合わせて単語を 抽出した。また、各実習に関する感想の分析は、
学生がそれぞれについて記述した文章を内容によつ て「鍼众実習・介護実習について」「関わり」「指 導教員・施設スタッフ」「経験」「その他」のカテ ゴリーに分けて分析した。

\section{2. 老年ケア実習の内容}

4 年次の老年ケア実習は、特別養護老人ホーム、 ケアハウスにおいて主に虚弱な高齢者や介護の必 要な高齢者を対象に鍼尒治療実習（以下、鍼尒実 習と略す）と介護 -介助実習（以下、介護実習と 略す）を行った。実習期間は、鍼尒実習 1 週間、 介護実習 1 週間の実習を前期、後期に分け合計 2 週間の実習を行った。鍼众実習では、鍼尒の担当 教員の指導のもとに、高齢者の治療室への移動の 介助、診察、治療を行った。鍼众実習中に時間を 設けて高齢者の身体的機能低下による不自由さを 体験する疑似体験を行った。介護実習では、介護 士等の指導のもとに虚弱な高齢者や介護の必要な 高齢者に対する介護・介助の実習を行った。実習 の初日に準備としての車椅子の操作法、移乗動作 や体位変換等の介護の仕方の指導、車椅子の乗車 体験等を行った。

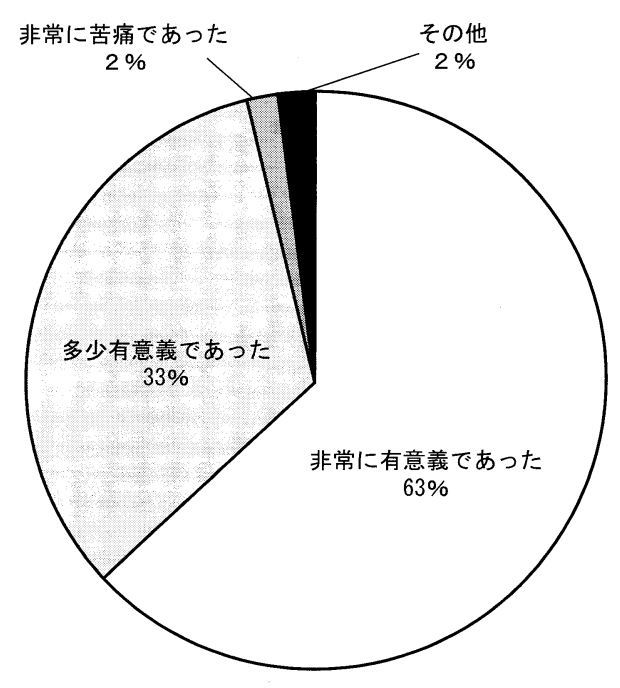

図1 実習の意義等に関する感想 学生 56 名の実習の感想のアンケート調査結果を示す。 
表 1 鍼炎実習・介護実習について学生の感想

\begin{tabular}{|c|c|c|}
\hline & 良かつた点 & 改善希望点 \\
\hline $\begin{array}{l}\text { 鍼众実習 } \\
\text { 介護実習 }\end{array}$ & 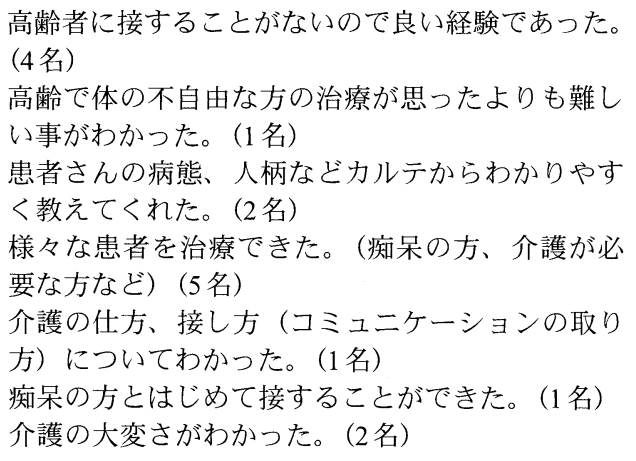 & $\begin{array}{l}\text { 同じ患者をもっと何回も治療し、経過を知りたい。 } \\
\text { (1名) } \\
\text { 治療法がある程度決まっている。マンネリ化してい } \\
\text { る。（1名） } \\
\text { 患者数が少ない。ベッド数が少ない。（1名） } \\
\text { 実習中、何もしない時間が多い。(介護実習)（1名） } \\
\text { 学生があまり介護の役に立っていない。（1名） } \\
\text { 食事介助、入浴介助は人見知りや恥ずかしがったり } \\
\text { するのでスタッフが行うほうが良いのではないか。 } \\
\text { (1名) } \\
\text { 苦痛でした。(介護実習)（3名） }\end{array}$ \\
\hline 関わり & $\begin{array}{l}\text { 高齢者、痴呆の方の接し方を学べた。（8名） } \\
\text { 患者さんとの接し方でいろいろな指導を受けたこ } \\
\text { とが良かった。(2名) }\end{array}$ & $\begin{array}{l}\text { 特養の実態を知り、少しショックを受けている。（1 } \\
\text { 名） } \\
\text { 癖のある老人について、一言アドバイスをしてくれ } \\
\text { たらもつと介助の工夫ができたと思う。（2名） }\end{array}$ \\
\hline 経 験 & $\begin{array}{l}\text { 実際に痴呆等のいろいろな疾患、患者と接する事 } \\
\text { ができた。 } \\
\text { 入所者に喜んでもらえたこと。 } \\
\text { とても貴重な経験ができた。（2名） } \\
\text { 疑似体験で障害を持つという事が少しわかり、今 } \\
\text { 後の人生に役立ちそうだ。(4名) } \\
\text { 普段経験できないことが経験できた。（1名） } \\
\text { 食事介助が良い経験になつた。（1名） } \\
\text { 施設を訪れたことがないので、訪問できて良かっ } \\
\text { た。(1名) }\end{array}$ & $\begin{array}{l}\text { 車椅子の移乗動作の指導をもつと長い時間して欲し } \\
\text { い。（1名） } \\
\text { 何の手がかりもなく会話をし続けることがつらかっ } \\
\text { た。（2名） } \\
\text { 寮母さんによってやること（指示してくれる事）が } \\
\text { 違つたので他の班とバラツキがあった。（1名） }\end{array}$ \\
\hline $\begin{array}{lr}\text { 教 } & \text { 員 } \\
\text { 施 } & \text { 設 } \\
\text { スタッフ }\end{array}$ & $\begin{array}{l}\text { 教員が熱心。（1名） } \\
\text { スタッフ（介護士）の体の強さを感じる。（1名） }\end{array}$ & $\begin{array}{l}\text { 介護で具体的に何をしたらいいのか分からない時が } \\
\text { 多かったので、少しは何をしたらいいのか言つて欲 } \\
\text { しい。(5名) }\end{array}$ \\
\hline その他 & $\begin{array}{l}\text { 現実の厳しさが分かった事がよかつた。（1名） } \\
\text { 様々な人をみて勉強になつた。実習生の対応など } \\
\text { から自分の対応を見つめなおすことができた。（1 } \\
\text { 名） } \\
\text { 日頃あまり考えていない事をやるので、いろいろ } \\
\text { 考えることができた。(1名) }\end{array}$ & \\
\hline
\end{tabular}

各害習に関する感想の文章を、「鍼尒実習・介護実習」「関わり」「指導教員・施設スタッフ」「経験」「その他」のカ テゴリーに分類した。

\section{III. 結 果}

アンケートの有効回答数は、実習前 106 名 $(89.6 \%) 、$ 実習後 56 名 $(47.5 \%)$ であった。

\section{1. 実習の意義等に関する感想}

実習後の学生の評価は「非常に有意義」 $63 \%$ 、

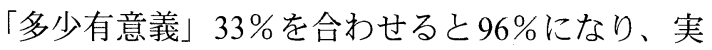
習が有意義であったとする学生が多かった（図 1)。

\section{2. 各実習に関する感想}

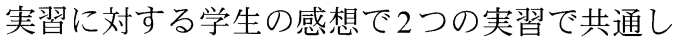
て良かつた点は、実際に痴呆をはじめ体の不自由 な様々な高齢者と接することができたことが挙げ られた。銊尒実習では、治療や疑似体験等によっ て高齢者や障害のある者の不自由さや大変さが理 解できたことであった。また、介護実習では、コ ミュニケーションに関することや関わりについて の感想があった。一方で、コミュニケーションに 関する戸惑いもみられた（表1）。 


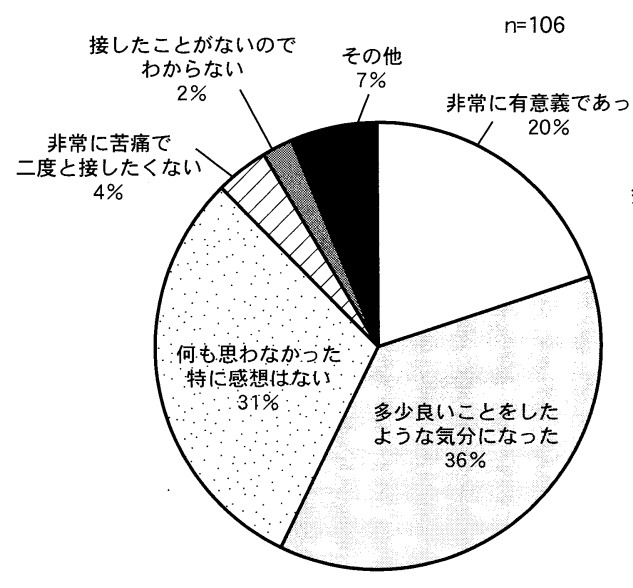

実習前

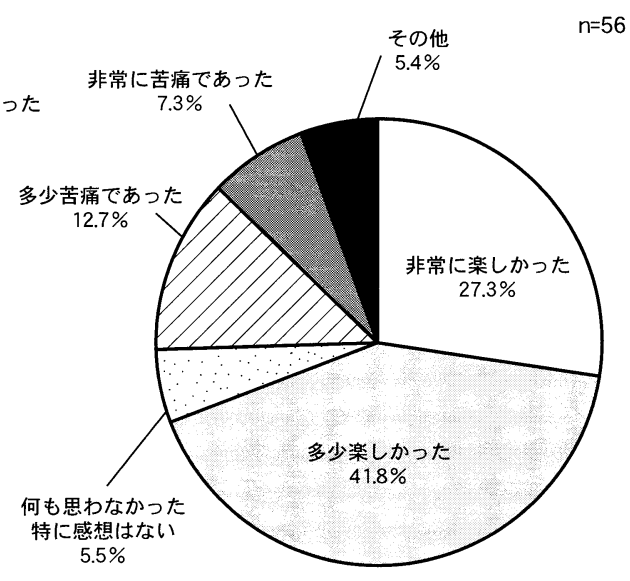

実習後

図 2 高齢者と接した感想

実習前後で学生が高齢者と接した感想のアンケート調査結果。

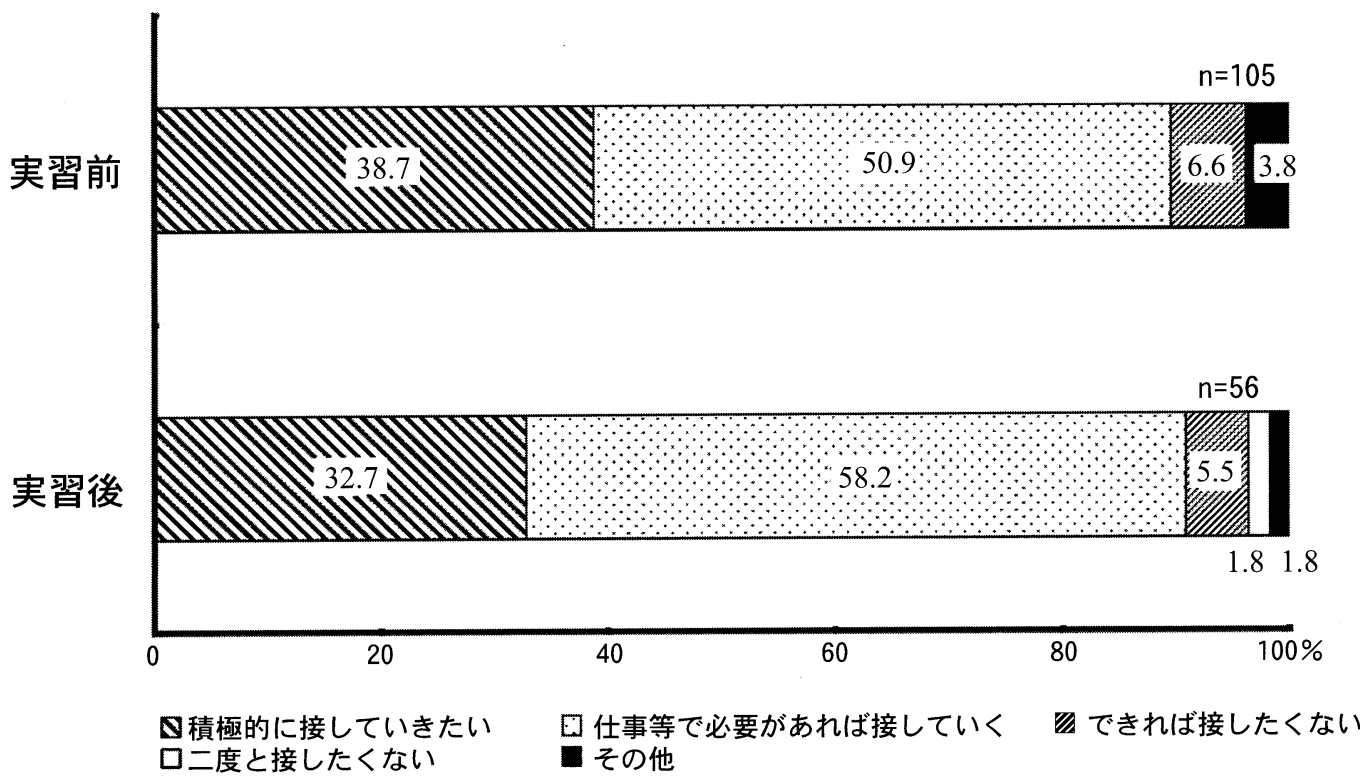

図 3 高齢者と今後接したいかどうかの気持ち.

実習前後で学生が高齢者と今後接したいかどうかの気持ちのアンケート調査結果。

3. 高齢者に接しての感想と今後の関わりについ $\tau$

実習を通して高齢者と接してみて、「非常に楽 しかつた」 $27.3 \%$ 、「多少楽しかつた」41.8\%で 計 7 割が楽しいと感じていた。一方で、多少ある
いは非常に苦痛と感じたものが2割みられた（図 2)。

今後の高齢者との関わりについては、実習後に 「積極的に接したい」 $32.7 \%$ 、「仕事等で必要があ れば接していきたい」58.2\%で合わせて $90.9 \%$ 
接することに肯定的であった。実習前後の回答者 数が異なるので厳密に比較することはできないが、 積極的に接したい者が減り、仕事等で必要があれ ば接していきたい者が増加した傾向を示したもの の、合計ではほぼ同じ傾向を示した。一方で「で きれば接したくない」や「二度と接したくない」 も、僅かではあるがみられた（図3）。

\section{4. 実習前後の高齢者に対するイメージの変化}

実習前の学生のイメージは、「精神機能」・「社
会的存在」ではプラスとマイナスのイメージの両 方があるが、プラスイメージの方が多く、身体機 能ではプラスの項目はなくマイナスイメージが多 かった（表2）。実習後に高齢者に対するイメー ジが変わらなかった者は 44\%（25名）、変わつた 者は 56\%（31名）であり、変わった者のうち具 体的な内容を記した学生は28名であった。変化 の内容は「痴呆があり、何をするにも人の助けが いること」「思ったより会話がむずかしい」等の 身体面や会話の難しさ等によってマイナスのイメー

\section{表2 実習前の高齢者に対するイメージ}

\begin{tabular}{|c|c|c|c|c|c|c|c|}
\hline \multicolumn{2}{|c|}{ カテゴリ- } & 項 目 & \multicolumn{3}{|c|}{ 人数|カテゴリ- } & 項 目 & 人数 \\
\hline & $\begin{array}{l}\text { 外 } \\
\text { 観 }\end{array}$ & $\begin{array}{l}\text { 弱い } \\
\text { 年齢を重ねている・年齢が高い } \\
\text { 腰が曲がってい・丸い } \\
\text { ヨボヨボ } \\
\text { 細い } \\
\text { 重い }\end{array}$ & $\begin{array}{l}1 \\
2 \\
2 \\
2 \\
1 \\
1\end{array}$ & 社 & $\begin{array}{l}\text { 生 } \\
\text { 活 } \\
\text { 者 }\end{array}$ & $\begin{array}{l}\text { 大金持ち } \\
\text { ゲートボール } \\
\text { 暇である } \\
\text { 一人暮らし } \\
\text { 定年 } \\
\text { 同じサイクルで生活している }\end{array}$ & $\begin{array}{l}1 \\
1 \\
1 \\
1 \\
1 \\
1\end{array}$ \\
\hline & \multirow[t]{2}{*}{$\begin{array}{l}\text { 身 } \\
\text { 体 } \\
\text { の } \\
\text { 衰 } \\
\text { え }\end{array}$} & \multirow{2}{*}{$\begin{array}{l}\text { ゆっくり } \\
\text { 動作が鈍い・動作が緩慢 } \\
\text { 足腰が弱い } \\
\text { 聂遠くて, 大きな声でないと聞こえない } \\
\text { 身体的に衰えがある } \\
\text { 体の自由が利かない } \\
\text { 若い人より体が弱い } \\
\text { 動きが鈍くて人の助けが必要になる } \\
\text { 病気や障害など不自由な面を色々持ち、QOL } \\
\text { が低い状態で日々を過ごしている人が多い } \\
\text { 何らかの不自由を抱えている人 } \\
\text { 色々な面で力の弱い人 } \\
\text { 自分で排泄物の処理が出来ない }\end{array}$} & $\begin{array}{l}1 \\
1 \\
2 \\
2 \\
3 \\
1 \\
1 \\
1\end{array}$ & $\begin{array}{l}\text { 会 } \\
\text { 的 } \\
\text { 存 } \\
\text { 在 }\end{array}$ & $\begin{array}{l}c \\
己 \\
\tau \\
の \\
\text { 視 } \\
\text { 点 }\end{array}$ & $\begin{array}{l}\text { 助けが必罗 } \\
\text { 社会的弱者である } \\
\text { 人生の先輩 } \\
\text { 人生経験豊富 } \\
\text { 勉強になる } \\
\text { 基本的な考え方や物事に対する興味は若い人 } \\
\text { たちと大差ない } \\
\text { おじいちゃん、おばあちゃん }\end{array}$ & $\begin{array}{l}1 \\
6 \\
1 \\
1\end{array}$ \\
\hline & & & $\begin{array}{l}1 \\
1 \\
1 \\
1\end{array}$ & & 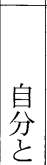 & 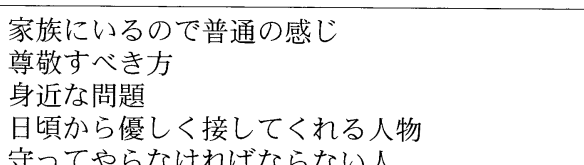 & $\begin{array}{l}2 \\
1 \\
1 \\
1 \\
1\end{array}$ \\
\hline & $\begin{array}{l}\text { 心 } \\
\text { 理 } \\
\text { 的 } \\
\text { 特 } \\
\text { 徵 } \\
\text { 性 } \\
\text { 格 }\end{array}$ & $\begin{array}{l}\text { 頑固な人 } \\
\text { やさしい } \\
\text { 気分屋 } \\
\text { 自分本位 } \\
\text { 素直なんが少ない }\end{array}$ & $\begin{array}{l}4 \\
1 \\
1 \\
1 \\
1\end{array}$ & 全 & $\begin{array}{l}\text { の } \\
\text { 関 } \\
わ \\
り\end{array}$ & $\begin{array}{l}\text { 若い人の力が必要 } \\
\text { 周りいる人々が年を取って守ってあげるべ } \\
\text { き対象に変わった人 } \\
\text { 自分の将来の姿 } \\
\text { いつか自分もそうなる }\end{array}$ & $\begin{array}{l}1 \\
1 \\
1\end{array}$ \\
\hline $\begin{array}{l}\text { 精 } \\
\text { 神 } \\
\text { 的 } \\
\text { 機 } \\
\text { 能 }\end{array}$ & $\begin{array}{l}\text { 知 } \\
\text { 的 } \\
\text { 特 } \\
\text { 徵 }\end{array}$ & $\begin{array}{l}\text { 物知り・知恵袋 } \\
\text { 気持ちが強い方 } \\
\text { 精神的にはなんら若い人と変わりない } \\
\text { 人生経験豊かな人 } \\
\text { いろんな事を知つている } \\
\text { 色々知らないことを教えてくれる } \\
\text { 自分より人生についてより大きなスケールを } \\
\text { 持つている } \\
\text { 呆けている } \\
\text { 昔話をする・昔のことばかり言う } \\
\text { よく話す・話が長い } \\
\text { 同じ事を何度も言う } \\
\text { 会話が上手く取れない } \\
\text { 性格が変わりやすく, すぐに愚痴を言う } \\
\text { 弱い立場 }\end{array}$ & $\begin{array}{l}2 \\
1 \\
1 \\
1 \\
1 \\
1\end{array}$ & $\begin{array}{l}\text { を } \\
\text { 描 } \\
\omega \\
た \\
\text { た } \\
x \\
1 \\
\vdots\end{array}$ & $\begin{array}{l}\text { 全 } \\
\text { 体 } \\
\text { 像 } \\
\text { を } \\
\text { 形 } \\
\text { 容 } \\
\text { 詞 } \\
\text { で }\end{array}$ & $\begin{array}{l}\text { かわいい } \\
\text { さみしい } \\
\text { 大きな赤ちゃん } \\
\text { 不安 } \\
\text { 不潔 } \\
\text { ひとり }\end{array}$ & $\begin{array}{l}1 \\
3 \\
1 \\
1 \\
1 \\
1\end{array}$ \\
\hline
\end{tabular}

記述のあつた学生 86 名の高齢者に対するイメージを「身体機能」「精神機能」「社会的存在」「全体像を描いたイメ一 汇に分類した。 
表3 実習後の高齢者に対するイメージの変化

\begin{tabular}{|c|c|}
\hline プラスイメージ & マイナスイメージ \\
\hline 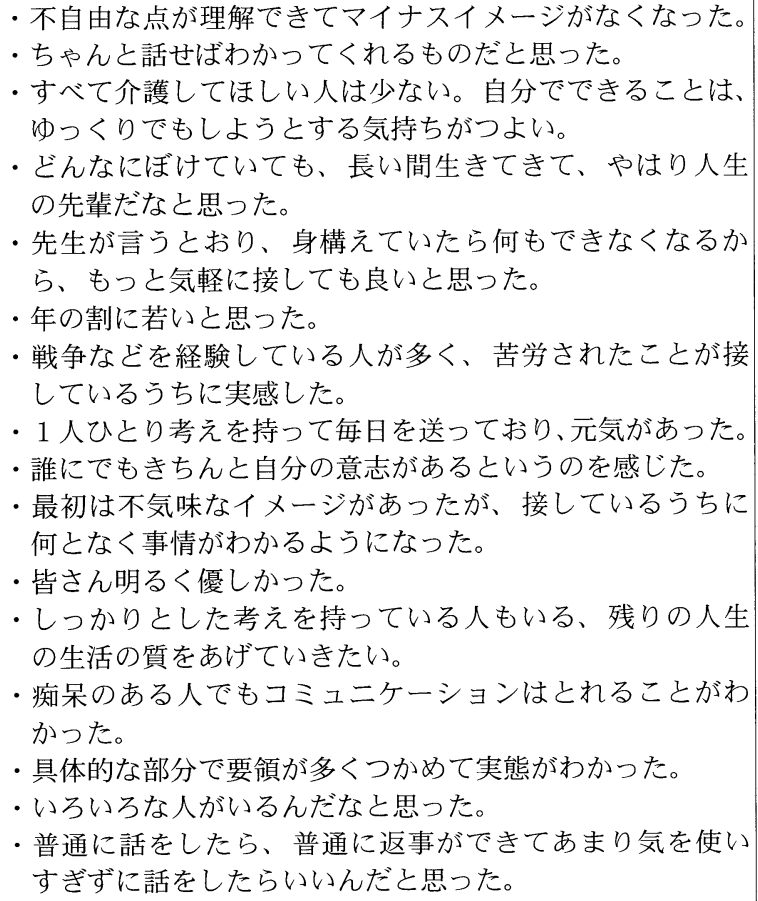 & 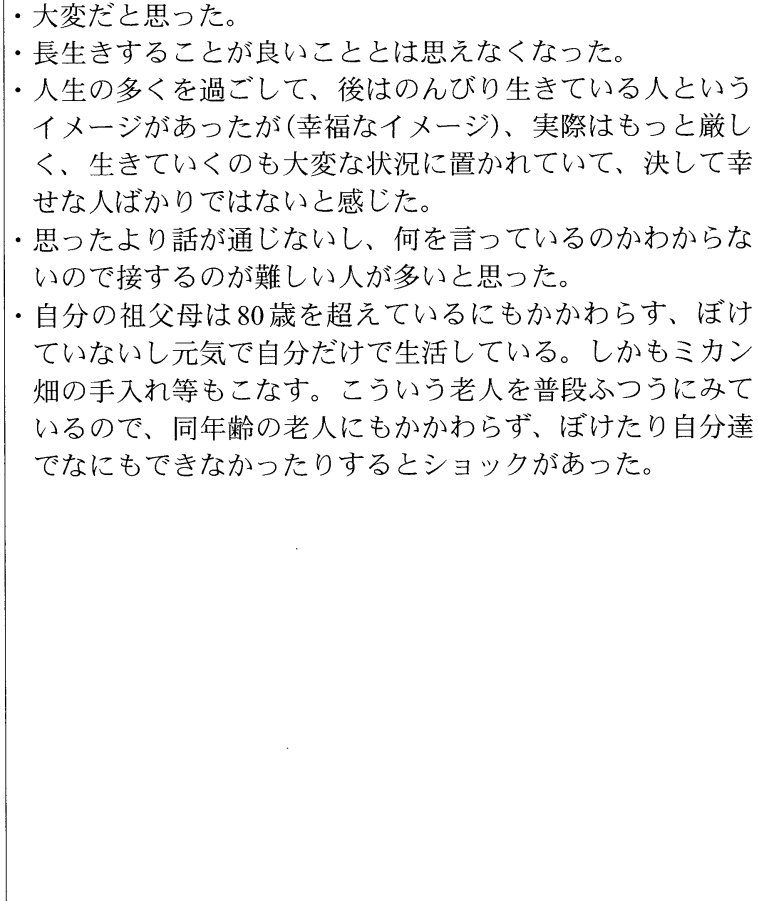 \\
\hline
\end{tabular}

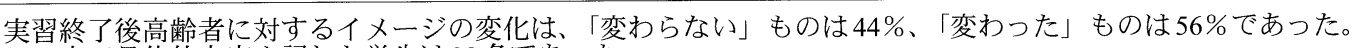
その中で具体的内容を記した学生は28名であった。

ジへ変化した学生が $16.1 \%$ （5名）みられたが、 「痴呆のある人でもコミュニケーションがとれる ことが分かった」、「不自由な点がよく分かった」 等プラスイメージへ変化した学生が54.8\%（17 名）でプラスイメージへの変化が多かった（表3）。

\section{IV. 考 察}

\section{1. 実習の意義に関する感想について}

実習に対しては、実習後9割の学生が「有意義」 と感じていた。明治鍼尒大学で実施されている他 の実習でも高齢者を対象とした治療は行われてい るが、特に虚弱な高齢者や介護の必要な高齢者を 対象には行われていないことから本実習を有意義 と感じた学生が多かったと考えられる。多田 ${ }^{2}$ は、 学生が高齢者に対する理解を深めるためには、教 育において多様な健康レベルにある高齢者に接す る機会を作ることが重要だと報告している。施設 での実習は、多様な健康レベルの入所者との関わ りを体験したことが理解を深めることにつながつ
たのではないかと考えられる。松本 ${ }^{3)}$ は、在宅や 施設ケアに鍼众治療を取り入れるには、適切に対 応できる能力が必要であり、鍼众師もある程度の 介護の知識や技術および老人福祉・保険制度の知 識を備えておくことが必要であると報告している。 このことから、本学の実習でも鍼众の臨床経験を 積み重ねるための鍼众実習とともに介護知識と技 術を習得するための介護実習を行う老年ケア実習 を平成 7 年度より行っており、事前のオリエンテー ションも行っているが、介護実習実施にあたって は事前に実習の重要性の理解をさらに図ることが 今後の課題であり、実際の実習カリキュラムの内 容充実等も今後の検討課題であると考える。

\section{2. 各実習で学生が感じたことについて}

銊尒実習では、「介護の必要な高齢者の治䝤が できた」「老人の接し方がわかった」「疑似体験で 高齢者や体の不自由な人の大変さが理解できた」 等の肯定的な意見が多かった。また、介護実習で 
は、「高齢者と接することができた」「コミュニケー ションがとれるようになつた」「介護の大変さが わかつた」等の意見があり、実習での様々なこと が体験でき、より理解が深まったことが明らかに なつた。

\section{3. 高齢者に接しての感想と今後の関わりについ $\tau$}

高齢者と接してみて非常に又は多少楽しかった と答えた者は7割あったが、今後積極的に接した い者は3割のみで少なく、必要があれば接したい という消極的な者が6割で多かった。金川 ${ }^{4}$ らは、 これらの実習では老人の特徵を知ることや、能力 に応じたケアの工夫や実践力の向上および自分の 家族の老後を考える機会になつたという利点があ る反面、高齢者の本来の姿や可能性が見えず、実 習によってかえって負の老人観を形成したり、ケ アの効果が少ないために学習意欲の向上につなが らないといつた問題点があることを指摘している。 今回の結果も、実習前には積極的に接したいと考 えていたが、現実としてマイナスのイメージを形 成したり、治療を行っても若い人のように急激な 変化が見られず介護ばかりをしているという印象 が強く残ってしまったり、対応の難しさ、戸惑い 等を感じたことが影響したのではないかと考えら れた。鍼尒実習では、介護が必要な高齢者を治療 する際、居室から診察室までの誘導、移乗動作、 ベッド上の体位変換、更衣および患者によっては トイレ介助なぞ、様々な介助を行わなければなら ず、また、痴呆の人や寝たきりの人と接した経験 のある学生は4 割のみで、半数以上が介護経験が なく、経験のある学生でも実際に介護を行った機 会が少なかったことから、実際の実習において戸 惑いや不安が強まり、その結果、積極的に接して いきたい気持ちになれなかった可能性も考えられ る。

\section{4. 実習後の高齢者に対するイメージの変化につ} いて

イメージが変化した者は $56 \%$ であり、具体的 な内容を記入した者のうちではプラスイメージへ の変化と思われる者のほうが約 $55 \%$ で多かった。
鍼炎実習では、一人のべ $5 \sim 10$ 人ほどの治療を行っ た。鍼众治療は、他の医療処置や介護等を行う場 合よりも時間がかかり、施設での治療の場合はそ れに加えて介助を行うためにコミュニケーション をとる時間が多く、相手を理解しやすかったもの と考えられる。また、介護実習でも担当を決めて 毎日食事介助を行い、また学生によっては痴呆の 人と接するなど様々な高齢者と接し、高齢者を理 解し易かったのではないかと考えられる。横山 ${ }^{5}$ は、少数の対象との関わりであっても、相手を十 分理解してケアを繰り返すという体験をとおして イメージは肯定的に変化すると報告している。今 回のイメージの変化も、高齢者との関わる時間が 多く、また疑似体験等を実習に取り入れたことに より高齢者への理解がさらに深まった結果である と思われる。佐藤 ${ }^{6}$ らは「体験学習では、老人の 生活を具体的に実感することで、心情的に老いへ の理解を進めることができ、また、老いを外見の みのイメージや老人に対する一般的な考え方でと らえるのではなく、老人の内面に気づくことがで きる」と報告している。また平出》らも、疑似体 験を通じて老人特有の傾向の理由がわかることで 自己の偏見に気づき、「のろいなあ」と思ってい た自分を恥じ、老人に優しくしてあげなければと いう気持ちになるなどの変化も生じることから、 体験学習が老人の内面に気づく実証の場となって いると報告している。また植村 ${ }^{8)}$ は「doing（行 動）は knowing（知識）からではなく、feeling (感動) から起こる」と述べていることからも、 疑似体験は効果的な教育方法であると思われる。 今後、疑似体験や車椅子介護法などの体験方法を 検討し、より良い体験ができるように検討したい と考える。

\section{5. アンケートの回収について}

今回は実習後のアンケート回収率が悪かったの で、実習後のアンケート項目に実習前のアンケー トを行ったかの確認するような項目を追加する必 要があったと考える。また、実習後の回収方法が 実習終了後 1 週間以内に各自アンケートの提出で あったため回収率が悪かったものと考える。今後、 回収率を高める工夫をし、再度検討したいと考え 
る。

\section{V. 結 語}

4年生を対象に老年ケア実習前後の高齢者に対 するイメージや老人観の変化、実習の感想等につ いてアンケート調査を実施した結果、以下のこと が分かった。

1. 高齢者を対象にした実習を「有意義」と考え ている学生は9割と多く、また高齢者と接した 感想も「楽しかった」と考えている学生が7割 いることが明らかになつた。

2.「今後、積極的に高齢者と接したい」と考え ている学生は3 割と少なく、「仕事等で必要が あれば接していく」が6割で最も多かった。

3. 高齢者に対するイメージは、実習後に変わつ たものが56\%で、そのうちプラスイメージへ の変化が約 $55 \%$ であった。マイナスのイメー ジは身体面や会話に関することが多く、プラス イメージは実習による高齢者への理解の深まり によることが明らかになった。

以上の結果から、介護等を必要とする高齢者を 対象とする実習では、高齢者の心身の特徴や対応 の仕方を理解するための事前の教育や、学習意欲 を高めるための動機づけが不可欠であり、さらに、 高齢者をより理解できるような疑似体験の事前指 導や、介護方法や高齢者とのコミュニケーション のとりかたなどの工夫の検討が必要であると考え る。

\section{謝 辞}

本調査を行うにあたり、ご助言ご協力いただい た元明治銊尒大学老年鍼尒医学教室助手 寺沢宗 典先生に深謝いたします。

\section{文 献}

1）水沼国男，寺澤宗典，高橋則人，鶴 浩幸，松 本 勅. 学生の高齢者のイメージに関する研究 （第 1 報）。明治鍼众医. 2003;（32）：25-35.

2）多田敏子. 老年看護学における臨地実習によ る看護学生の高齢者に対する印象の変化. 老年 看護学. 2003; (1)：63-70.
3）松本 勅. 高齢化社会における鍼众の活用-高 齢者に対する鍼众治療の実践の立場から一，全 日鍼众会誌. 2001；51(1)：35-8.

4）金川克子. 老人介護実習の場をめぐつて. 看 護展望. 1998；13(5)：22-6.

5）横山裕子，藤田和子. 老年看護実習前後での 看護学生イメージの変化. 看護教育. 2000；513.

6）佐藤弘美, 永江美千代, 黒田久美子, 正木治恵 他. 老人理解のための体験学習. 看護展望. 1993; $18(8): 32-5$.

7）平出恵子, 小高京子. 看護学生の老人に対す る疑似体験. 看護教育. 1996; 131-4.

8）植村研一. 効果を高める講義の原則. 看護教 育. 1990; $31(8)$ : 454-61. 


\title{
Research Report
}

\section{A Study on the Images of Elderly People in Oriental-Medical University Students \\ - Changes in the Students' Image of Elderly people after Practice in a Nursing Home -}

\author{
MIZUNUMA Kunio ${ }^{1)}$, TAKAHASHI Norihito ${ }^{2)}$ \\ TSURU Hiroyuki ${ }^{2)}$, MATSUMOTO Tadasu ${ }^{2)}$
}

1) Department of Basic Oriental Medicine, Meiji University of Oriental Medicine

2) Department of Geriatric Acupuncture and Moxibustion, Meiji University of Oriental Medicine

\begin{abstract}
[Objective] There are two types of image the students have towards elderly people, positive and negative, and it is thought to be difficult for students to interact with elderly people when negative images are the most powerful. Changes in the students' feelings towards elderly people during their time in a nursing home are of importance when assessing the project's educational effectiveness. Given this factor, we have researched the changes in the students' impression towards elderly people before and after the project.

[Method] We carried out a research questionnaire before and after the project.

[Results] Number of valid response was 106 before the project (response rate 89.8\%), and 56 after the project (response rate $47.5 \%)$. Over half $(56 \%)$ of the students said that their image of elderly people changed after the project. Negative image comes from realising elderly people's physical disability and difficulty in having conversations with them, and positive image comes from understanding elderly people more by interacting with them.

[Conclusions] Although there was a growing awareness of elderly people and some of the students changed their feeling towards them, there are still students who have a negative image. We think that it is important to provide methods of approaches before and during the project to minimise these negative images.
\end{abstract}

Zen Nippon Shinkyu Gakkai Zasshi (Journal of the Japan Society of Acupuncture and Moxibustion: JJSAM). 2005; 55(1): 56-64. Received June 16, 2004; Accepted November 8, 2004

Key words: questionnaire, images of the elderly, nursing practice, student. 